\title{
Papillomatosis cutis carcinoides két esete
}

\section{Two cases of papillomatosis cutis carcinoides}

\author{
MAJOROS TIBOR DR., KÁROLYI ZSUZSÁNNA DR. \\ Miskolci Semmelweis Kórház és Egyetemi Oktatókórház Bőrgyógyászati Osztály, \\ Miskolc, Magyarország
}

\section{ÖSSZEFOGLALÁS}

A papillomatosis cutis carcinoides egy ritkán elöforduló, a verrucosus carcinomák csoportjába tartozó entitás, mely leginkább időskorú betegek körében jelentkezik. Az elváltozás jellemzöen az alszárra lokalizálódik, lefolyását tekintve krónikus, exstirpációját követöen recidíva készsége nagy. A verrucosus felszínü, akár tenyérnyi nagyságot is elérő szövetszaporulat mind a gyakorló börgyógyász, mind a szövettani mintát véleményező patológus számára komoly differenciáldiagnosztikai problémát okozhat. A szerzók két esetet mutatnak be. Mindkét beteg évek óta fennálló, terápia rezisztens ulcus cruris miatt állt gondozás alatt. Kezelésük során a fekélyben karfiolszerü szövetszaporulat alakult ki, mely felvetette malignus folyamat lehetôségét, az ismételten elvégzett próbaexcisiók hisztológiai feldolgozása során azonban benignus elváltozást véleményeztek.

Kulcsszavak: papillomatosis cutis carcinoides verrucosus carcinoma - szövettan differenciáldiagnosztika

\section{SUMMARY}

Papillomatosis cutis carcinoides is a rare disorder from the group of verrucous carcinomas, which occurs mostly in the elderly. The lesion is tipically localized in the lower leg, and has chronic course; after removal recurrance is frequent. The tumor has verrucous surface, and can reach the size of one palm, which could cause differential diagnostic problem for both dermatologists and pathologists. Hereby, the authors present two cases: both patients were resistent to therapy, and a cauliflower-like tissue mass formed after years of persistance in the ulcers. This papillomatosus tumor raised the possibility of malignancy, but histological examinations carried out in different time points considered benign dignity.

A papillomatosis cutis carcinoidest elsóként Gottron írta le 1932-ben. Ezen entitás a verrucosus carcinomák csoportjába tartozik a florid oralis papillomatosis, az epithelioma cuniculatum és a Buschke-Löwenstein tumor mellett (1. táblázat) (1,2,3). A bőrre és nyálkahártyára lokalizálódó verrucosus carcinomák ritkán előforduló, alacsony grádusú, magasan differenciált laphámrákok, melyekre klinikailag a lassú, exofitikus növekedés jellemző. Csak kivételes esetekben metasztatizálnak a regionális nyirokcsomókba; elsősorban többszöri recidíva, vagy megelőző sugárkezelés kapcsán fellépő anaplasztikus transzformáció következtében; távoli áttétet csak néhány esetben észleltek $(4,5)$. Hisztológiailag lokális invazivitást és minimális dysplasiát mutatnak $(1,3,5)$.

\begin{tabular}{|c|}
\hline Verrucosus carcinomák \\
\hline Cutan \\
\hline- epithelioma cuniculatum \\
\hline- papillomatosis cutis carcinoides \\
\hline Oropharyngealis \\
\hline- florid oralis papillomatosis \\
\hline Genitoanalis \\
\hline- Buschke-Löwenstein tumor \\
\hline
\end{tabular}

1. táblázat

A verrucosus carcinomák felosztása

Levelező szerző: Dr. Majoros Tibor, Miskolci Semmelweis Kórház és Egyetemi Oktatókórház, Bőrgyógyászati Osztály, 3529 Miskolc, Csabai kapu 9-11. e-mail: tibormajoros@freemail.hu 


\section{Esetismertetés}

\section{I. eset}

A 88 éves nőbeteg anamnézisében cholecystectomia, hysterectomia, diabetes mellitus és hypertonia szerepel. 2004. februárjában a tíz éve háziorvosa által kezelt ulcus cruris progressziója miatt került felvételre osztályunkra. Felvételekor a bal lábszár lateralis oldalán több tenyérnyi, sárgás lepedékkel fedett, nagyrészt túlsarjadt, helyenként exofitikus növedéket mutató ulcus volt látható ( 1 . ábra). A klinikai kép alapján felmerült malignus elfajulás lehetősége, ezért az exofitikus területből lokális anesztéziában próbakimetszést végeztünk. A hisztológiai vizsgálat (2. ábra) pseudoepitheliomatosus hám hyperplasiát véleményezett, malignitást nem írt le. A rosszindulatú elfajulás biztos kizárása céljából az elváltozás másik területéből szintén mintát vettünk, a szövettani vélemény az előzővel megegyezett. Hasi és kismedencei UH, valamint mellkas rtg vizsgálat során kórosat nem írtak le. Lokális kezelés mellett a beteget otthonába bocsátottuk. Kontroll vizsgálatokon nem jelent meg, a kórház számítógépes adatbázisa alapján lábszárfekélyét sebészeti szakrendelésen gondozták. 2005. januárjában azonban kifejezett progresszió, fájdalom miatt femoralis amputacio történt. A rendelkezésünkre álló biopsziás anyagból utólagosan HPV PCR vizsgálatot végeztettünk (GenoID Kft., Budapest), mely negatív eredményt adott.

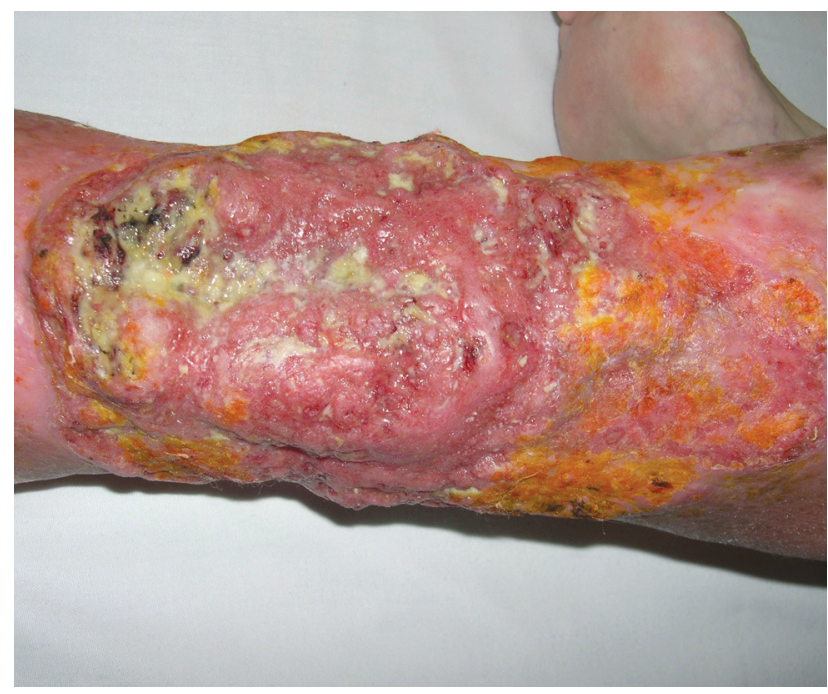

1. ábra

Nagyrészt túlsarjadt, helyenként exofitikus növedéket mutató ulcus (I. eset)

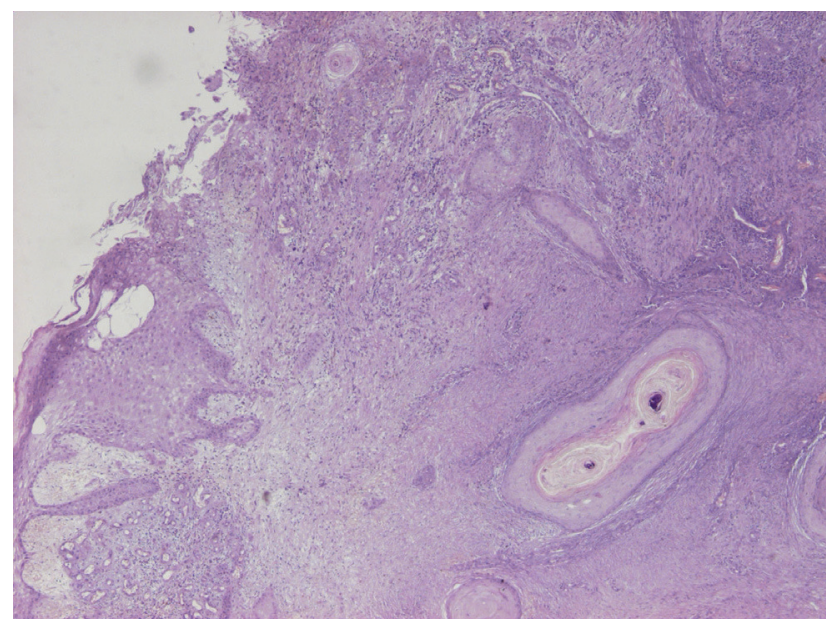

2. ábra

Az I. eset ulcusából vett minta szövettani képe (HE, 4X)

\section{II. eset}

A 86 éves nőbeteg kórelôzményében hypertonia, ischaemiás szívbetegség, valamint a bal lábszáron korábban lévő fekély plasztikai fedése szerepel. 2010-ben a bal lábszár ulcusa recidivált, majd rövidesen a fekély alapján karfiolszerú növedék jelentkezett. A területileg illetékes bőrgyógyászati osztályon a klinikailag neoplasztikus területből több alkalommal próbakimetszés történt, azonban a szövettani vizsgálat során malignitást igazolni nem tudtak, benignus papillomatosist véleményeztek. A fekélyalapon lévô növedék progressziót mutatott, helyi kezelésekre teljes mértékben rezisztens volt, ezért a beteget 2011. augusztusában osztályunkra irányították. Felvételekor a fekélyalapot teljesen kitöltô, verrucosus felszínú, odorosus szövetburjánzás volt látható (3. ábra). Az

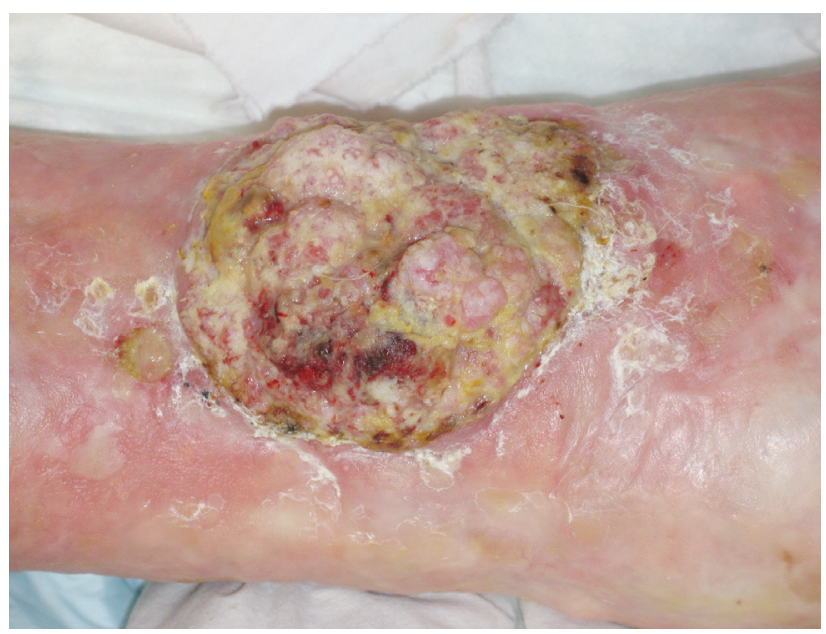

\section{3. ábra}

Az ulcust kitöltô, verrucosus felszínú, odorosus szövetburjánzás (II. eset)

elváltozásból osztályunkon lokális anesztéziában próbakimetszést végeztünk; a szövettani vizsgálat során acanthoticus, hyperkeratosist mutató polypoid bőrrészletet írtak le, ahol a dermis vizenyősen fellazult volt, illetve alapjánál lobos kötőszövetrészlet látszott; az elváltozást benignusnak véleményezték (4. ábra). Plasztikai sebésszel konzultálva a lézió in toto kimetszése mellett döntöttünk (2011. október). Az excindátum szövettani feldolgozása során benignus papilloma planocellulare verrucosum cutist írtak le, az épben kimetszve. Sebészeti javaslatra az elváltozás nyitott kezelését végeztük, mely során a sebalap felsarjadt, azonban az ulcus területében recidívát észleltünk (5. ábra), majd rövidesen ismét az egész fekélyt szövetszaporulat töltötte ki. Az elváltozás szövetdestruktív

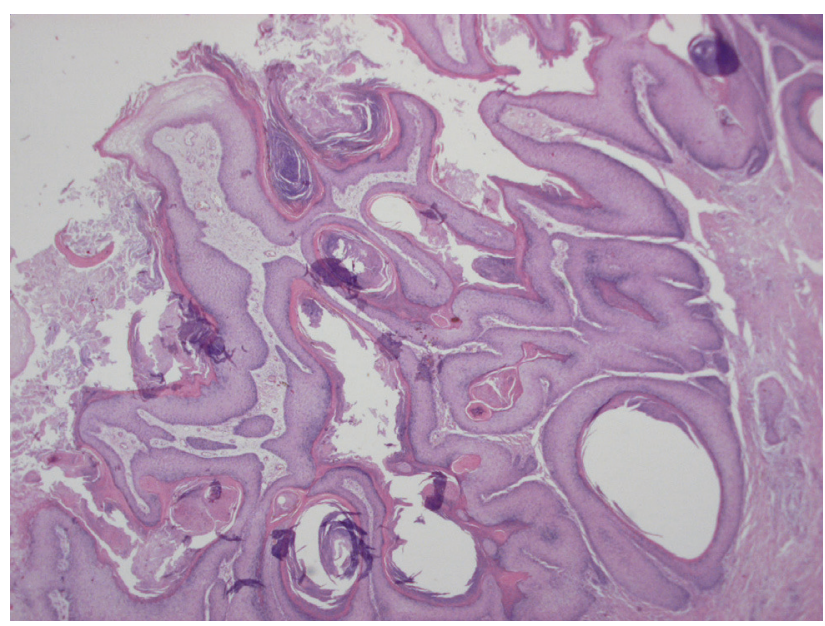

4. ábra

Az ulcusban kialakult elváltozás szövettani képe (II. eset)

(HE, 2X) 


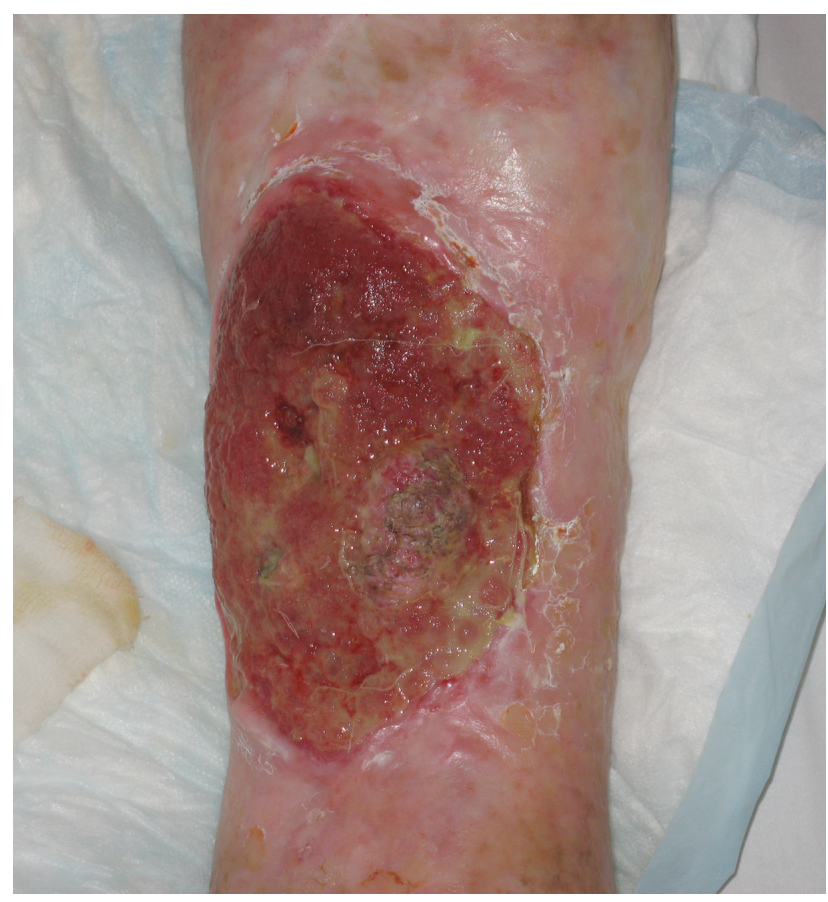

5. ábra

Az excisiot követôen rapidan kialakult recidíva

(II. eset)

helyi kezelésre $\left(\mathrm{AgNO}_{3}\right.$ rúd) teljesen rezisztens volt, napról-napra szemmel látható növekedést mutatott. 2012. februárban szélesen az épben reexcisiót végeztünk. Szövettani vizsgálat során a kimetszett anyagban a patológus carcinoma planocellulare verrucosum invasivumot véleményezett. Staging vizsgálatok során (mellkas rtg, hasi, kismedencei és inguinalis UH vizsgálat) disszeminációra utaló eltérést nem észleltünk. Az anyagból HPV PCR vizsgálatot kértünk (GenoID Kft., Budapest), mely negatív eredményt adott. Lokális kezelés mellett a sebalap felsarjadt, kifejezett széli hámosodás indult, recidíva nem volt észlelhetó.

\section{Megbeszélés}

A papillomatosis cutis carcinoides fő́ként idős emberek körében elôforduló, jellemzően a lábszárakra lokalizálódó, ritka entitás (1). Kialakulhat de novo, azonban jellemzóen valamilyen krónikus folyamat talaján jelentkezik (ulcus cruris, lupus vulgaris, vegetáló pyoderma, decubitus, égési heg, amputációs csonk, osteomyelitises fistula, krónikus vénás elégtelenség) $(1,4,5)$. Az etiológiai tényezők között a krónikus gyulladás és a humán papilloma vírus (HPV 1,11,18) a legjelentôsebbek $(1,5$, 6, 7). Eseteink kapcsán HPV kóroki szerepét bizonyítani nem tudtuk. A lézió karfiolszerú, felhányt széllel határolt, felszíne legtöbbször lepedékkel és pörkkel borított, lassan penetrál a környezố szövetekbe, destruálja a lágyrészeket és a csontokat $(1,4,5)$. Az odorosus jelleget a papillomatosus szövetek közötti detritusz, bakteriális szuperinfekció okozza (5). Az ulceració nem jellemzó. Az elváltozás spontán remissziója nem várható, legtöbb esetben évek alatt lassú progresszió észlelhető (1). Differenciáldiagnosztikai szempontból vírusos szemölcsök, reaktív epidermalis hyperplasia, óriás seborrhoeas keratosis, pyogen granuloma, óriás keratoacanthoma, ekkrin syringofibroadenoma, mély gombás fertózések és neoplasmák merülnek fel $(1,5,6)$.
Szövettani diagnózisa rendkívül nehéz, sok esetben a hiányzó, vagy minimális dysplasia és magasan differenciált volta miatt benignus elváltozást véleményez a vizsgáló. Hisztológiai vizsgálat céljából feltétlenül széles és mély biopsziás minta szükséges (4). A lézió teljes szerkezetének részletes vizsgálata elengedhetetlen a helyes diagnózis felállítása érdekében, illetve nagy jelentőséggel bír a tumor alapjának cytomorfológiája (5). Felszínes biopsziás minta esetén téves diagnózis születhet és a léziót jóindulatú pseudoepitheliomatosus hyperplasiának írhatják le $(5,8)$. Eseteink kapcsán ez fontos szerepet játszhatott a pathológus általi benignus megítélésben. A teljes architektúrát tekintve a lézió legtöbbször két komponensből, egy exofitikus és egy endofitikus részből tevődik össze $(4,5)$. Az exofitikus területen kifejezett papillomatosis látható hyperkeratosissal, acanthosissal, időnként parakeratosissal $(4,5,8,9,10)$. Jellemzó a granuláris sejtréteg vacuolizációja $(4,8)$. Vaskos, gumós hámcsapok, illetve ujjszerú projekciók alkotják az endofitikus komponenst. Ezen a területen szinuszok és keratinnal kitöltött cysták, kripták észlelhetôek $(5,8)$. A basalis membrán intakt $(4,5,8)$. A keratinocyták nem, vagy minimális dysplasiát mutatnak; mitózisok csak elszórtan, leginkább a basalis sejtsor mentén láthatóak; sejtnecrozis, dyskeratosis, illetve multinuclearis keratinocyták jelenléte nem jellemző. A keratinocyták általában nagy méretúek, kifejezett sejtmaggal és prominens nucleolusszal bírnak $(4,5)$. Az individualis cytomorfológiát tekintve benignus megjelenés jellemzó (4). A tumor stromája vizenyősen fellazult, krónikus gyulladásos sejtekből álló infiltrációt mutat $(4,8)$.

Terápiáját tekintve - amennyiben azt a lokalizáció és kiterjedés lehetôvé teszi - a széles alapú sebészi kimetszés az elsőként választandó $(1,9)$. Recidívakészsége igen kifejezett, a lokális kiújulások minél koraibb eltávolítása ajánlott (5). II. esetünk kapcsán a lezió in toto kimetszése után kialakult recidíva során egy rapidan növekvő szövetburjánzás volt észlelhetô, ami szemmel láthatóan, szinte napról-napra növekedett. Nagy kiterjedésú és rekurráló léziók esetén a Mohs -féle sebészi eljárás javasolható (5). Azon formák esetén, ahol a kimetszés nem végezhetó el, citosztatikumok (bleomycin, methotrexate), illetve retinoidok alkalmazhatók $(1,5,11)$. Biczó és $m t s a i$. per os etretinát kezelés mellett a lézió regresszióját írták le (11). Radioterápia az anaplasticus átalakulás lehetősége miatt nem ajánlott, azonban válogatott esetekben, kiterjedt tumor méret esetén preoperatív irradiáció alkalmazható a szövetmassza megkisebbítése céljából $(5,9)$. Nagyméretú tumornál, ami technikailag nehezen eltávolítható, INF-alfa kezeléssel elfogadható terápiás eredmény érhetố el, illetve a tumor olyan mértékú regressziója következhet be, melynél az excisió már kivitelezhetô (5).

A papillomatosis cutis carcinoides bár ritka elófordulású kórkép, azonban ismerete fontos a gyakorló bőrgyógyász számára, mert fennállása esetén komoly differenciáldiagnosztikai és terápiás problémát okozhat. Ismertetett eseteinkkel egy ritka kórképet szerettünk vol- 
na bemutatni, illetve felhívni a figyelmet arra, hogy krónikusan fennálló ulcusokban kialakuló szövetszaporulat esetében többszörös, mély biopszia végzése javasolt a malignus transzformáció kizárása, esetleges bizonyítása céljából.

\section{Köszönetnyilvánítás}

A szerzők szeretnének köszönetet mondani $d r$. Mórocz István pathológus fóorvos úrnak (Miskolci Semmelweis Kórház és Egyetemi Oktatókórház Pathológia Osztály) a szövettani metszetek fotóinak elkészítéséért, rendelkezésükre bocsájtásáért.

\section{IRODALOM}

1. Burgdorf W. H. C., Plewig G., Wolff H. H., és mtsai.: BraunFalco's Dermatology, 3rd ed., Springer. (2009) 1363-1364.

2. Schwartz R. A.: Skin Cancer: Recognition and Management, 2nd ed., Blackwell. (2008) 53-54.

3. Bolognia J. L., Jorizzo J. L., Schaffer J. V.: Dermatology, 3rd ed., Elsevier. (2012) 1310, 1782
4. Schwartz R. A.: Verrucous carcinoma of the skin and mucosa. J Am Acad Dermatol. (1995) Jan; 32 (1), 1-21.

5. Garbe C., Dummer R., Kaufmann R., és mtsai.: Dermatologische Onkologie, Springer. (1997) 196-200.

6. Noel J. C., Peny M. O., Goldschmidt D., és mtsai.: Human papillomavirus type 1 DNA in verrucous carcinoma of the leg. J Am Acad Dermatol. (1993) Dec; 29 (6), 1036-8.

7. Garven T. C., Thelmo W. L., Victor J., és mtsai.: Verrucous carcinoma of the leg positive for human papillomavirus DNA 11 and 18: a case report. Hum Pathol. (1991) Nov; 22 (11), 1170-3.

8. Assaf C., Steinhoff M., Petrov I., és mtsai.: Verrucous carcinoma of the axilla: case report and review. J Cutan Pathol. (2004) Feb; 31 (2), 199-204.

9. Ruppe R. P., Verrucous Carcinoma. Papillomatosis Cutis Carcinoides. Arch Dermatol. (1981) Mar; 117 (3), 184-5.

10. Rigel D. S., Friedman R. J., Dzubow L. M., és mtsai.: Cancer of the Skin. 1st ed., Elsevier. (2005) 144

11. Biczó Z., Nagy G., Fekete J.: Papillomatosis cutis carcinoides etretinát kezelése. Orv Hetil. (1993) Apr; 134 (16), 863-6.

Érkezett: 2013. 05. 10.

Közlésre elfogadva: 2013. 05. 18.

\section{HAZAI HÍREK}

\section{Kedves Kollégák!}

A DEOEC Bôrgyógyászati Klinika, valamint a Bőrgyógyászati Allergológiai Tanszék szervezésében Dr. Hunyadi János Professzor urat 70. születésnapja alkalmából köszöntjük tudományos ülés keretében 2013. szeptember 27-én, $\mathbf{1 0 . 0 0}$ - 13.00 h időpontban, melyre szeretettel várjuk a kollégákat.

Helyszín: Divinus Hotel, Debrecen.

A naptárba a fenti dátumot bejegyezni szíveskedjenek.

A programot a későbbiekben küldjük.

Debrecen, 2013. július 22.

Üdvözlettel és köszönettel, a Szervezôk:

Prof. Dr. Remenyik Éva

Prof. Dr. Szegedi Andrea 